\title{
APPLICATION OF RECOMBINANT DNA METHODS FOR PRODUCTION OF CHOLINESTERASES AS ORGANOPHOSPHATE ANTIDOTES AND DETECTORS*
}

\author{
Palmer TAYLOR ${ }^{1}$, Elsa REINER ${ }^{2}$, Zrinka KOVARIK ${ }^{1,2}$, and Zoran RADIĆ ${ }^{1}$ \\ Skaggs School of Pharmacy \& Pharmaceutical Sciences, University of California, San Diego, \\ La Jolla, CA, USA ${ }^{1}$, Institute for Medical Research and Occupational Health, Zagreb, Croatia ${ }^{2}$
}

Received in August 2007

Accepted in August 2007

\begin{abstract}
To develop new avenues for synthesizing novel antidotes for organophosphate poisoning and for detection of the organophosphates, we have turned to recombinant DNA methods to synthesize cholinesterases with unusual properties. For antidotal therapy we describe mutations of the native mouse and human enzymes that allow for enhanced rates of oxime reactivation. Such enzymes, when localized in the circulation, would enable the circulating cholinesterase to become a catalytic rather than simply a stoichiometric scavenger. Hence, "oxime-assisted catalysis" provides a means for scavenging the organophosphates in the circulation thereby minimizing their tissue penetration and toxicity. Accordingly, the oxime antidote or prophylactic agent has a dual action within the circulation and at the tissue level. Second, through a novel chemistry, termed freeze-frame, click chemistry, we have used organophosphate conjugates of acetylcholinesterase as templates for the synthesis of novel nucleophilic reactivating agents. Finally, acetylcholinesterase can be modified through cysteine substitution mutagenesis and attachment of fluorophores at the substitution positions. When linked at certain locations in the molecule, the attached fluorophore is sensitive to organophosphate conjugation with acetylcholinesterase, and thus the very target of insecticide or nerve agent action becomes a detection molecule for organophosphate exposure.
\end{abstract}

KEY WORDS: acetylcholinesterase, fluorescent acetylcholinesterase, organophosphate inhibitors, oxime antidotes, oxime-assisted catalysis, reactivation kinetics, remote detection, in situ - click chemistry, template-guided drug design

Over the last decade, developing means for detection of organophosphates and synthesizing new antidotes or prophylactic agents for organophosphate exposure have been accorded considerable attention $(1,2)$. This arises more out of concern of organophosphates being used in terrorism, rather than their applicability as chemical warfare weapons. Even in the absence of such insidious threats, organophosphate pesticides remain in widespread use in the home, garden and agricultural industry across the globe. Accessibility of these compounds thus warrants consideration of new chemical approaches to their detection and antidotal therapy following inadvertent exposure. In contrast to many compounds considered in threatened or actual terrorism or in use as pesticides, the organophosphates are directed to a discrete target of known structure at atomic resolution and have a well-defined mechanism of action $(2,3)$.

\footnotetext{
* Partly presented at the EUROTOX 2006/6 CTDC Congress - Symposium on Molecular Mechanisms of Organophosphates, Cavtat, Croatia, 20-24 September 2006.
} 
Advances in antidotal therapy have largely arisen from the original concepts of Irwin Wilson and his colleagues over 50 years ago, when he described the principles of site-directing nucleophiles to the active centre of the enzyme to break the phosphoester bond in the conjugated enzyme (Figure 1) (4). It was this approach that led to the development of the first pyridinium aldoxime (2-PAM) used as an antidote in organophosphate poisoning. Over the intervening years, some improvements have occurred in the development of other oximes and the use of a combination of muscarinic antagonists and seizure suppressing agents to control symptoms. Despite the developments in cloning the $\mathrm{AChE}$ gene (5-7), and the determination of the structure of the enzyme $(8,9)$ from several sources, this structural information has yet to be fully applied to the development of superior antidotes or detection agents (2). We show here how structure might guide the development of selective cholinesterase inhibitors, novel reactivating agents and organophosphate exposure detectors. The approach relies heavily on core structural information from crystallography, enhanced by detailed information on the structural dynamics of the target derived from mutagenesis, computational and physical measurements of the dynamics of the molecule (10-12).

Development of Novel Ligands Through FreezeFrame, Click Chemistry

Through collaboration with Dr. Barry Sharpless' group and through the use of the click chemistry methods developed in that laboratory (13), we have employed the AChE template for the design of selective inhibitors based on peripheral site (propidium derivatives) and active centre inhibitors (acridine derivatives) as building blocks. This approach relies on a bioorthogonal reaction between an acetylene and an azide; both are tethered through reversible binding to separate sites on the molecule to form a stable triazole (Figure 2). By combinatorial syntheses, great selectivity can be acquired in terms of regional isomers of the four possible substituted triazoles and the chain length between anchoring positions on the acetylene and azide building blocks. Hence, we can start with libraries of building blocks, allow the reaction to occur on the very target of drug action as the reaction vessel, and isolate the products formed by mass spectrometry. Although, as expected, the reaction occurs with one to one stoichiometry on the template, the higher molecular weight reaction product can be isolated from the reaction mix and easily identified by mass spectrometry (13). The studies revealed the selectivity of the reaction in terms of syn versus anti preferences. Moreover, the inhibitors formed on the template reveal the capacity to select unique or minor abundance conformations of $\mathrm{AChE}$ in the formation of the high affinity complex (14). Refinement of building block molecules has yielded cholinesterase inhibitors with $K_{\mathrm{d}}$ values approaching $1 \mathrm{fmol} \mathrm{L}^{-1}$ to 2 fmol $\mathrm{L}^{-1}$, a value that can only be measured accurately through the kinetics of association and dissociation.

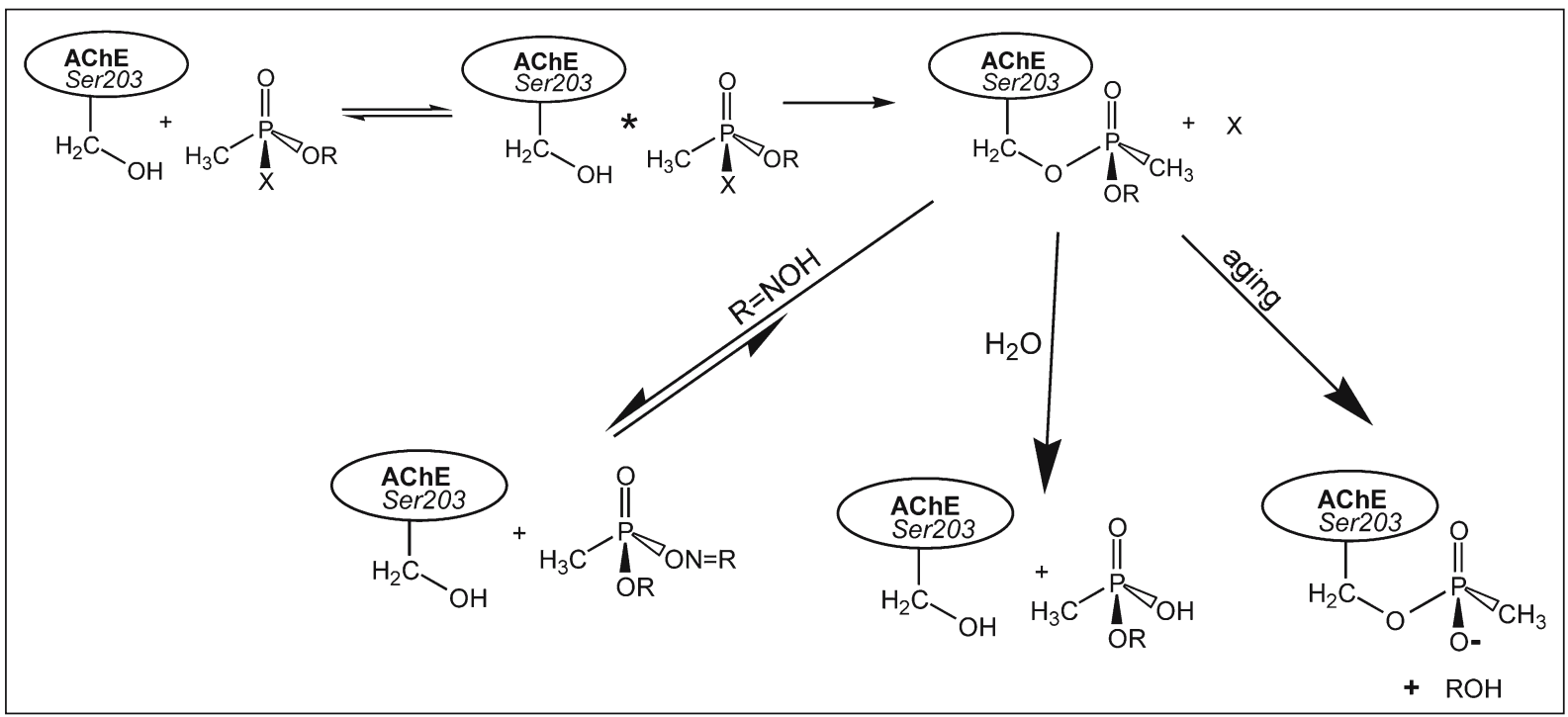

Figure 1 Reaction cycle for alkyl phosphate hydrolysis catalyzed by acetylcholinesterase and an oxime. Shown here are the phosphorylation step rendering the enzyme inactive followed by reactivation spontaneously or promoted by an administered oxime. In addition, an aging reaction can occur where the conjugate loses an alkoxy group rendering it largely resistant to oxime reactivation 


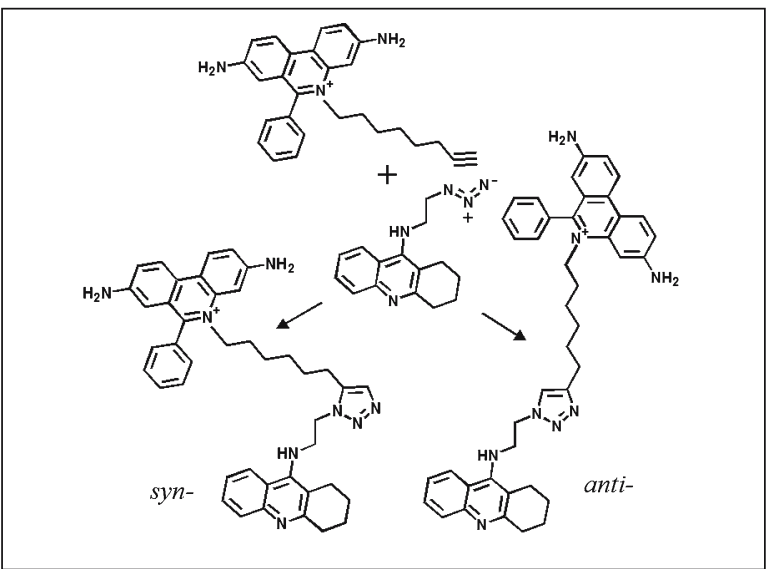

Figure 2 Reaction of the acetylene and azide building blocks to form syn- and anti-triazole inhibitors of acetylcholinesterase

Other refinements have eliminated the quaternary groups in the building blocks and diminished their size to allow blood-brain barrier penetration (15). In addition, by developing building blocks where steric clearance in the acyl pocket of the active centre is altered, specificity toward the insect $A C h E$ versus the mammalian AChE can be achieved (16).

To use this approach in the development of superior reactivating agents, one should consider several strategies. First, the template for the reaction might be the AChE-organophosphate conjugate, instead of the apo-enzyme in the case of inhibitor development (Figure 3). Although the triazole inhibitors form rapidly on the enzyme surface, the more stable organophosphate conjugates should be used as templates for this purpose. Accordingly our initial approach has involved synthesis of binding blocks for triazole formation or the triazole itself containing an oxime moiety. Variations on this theme will be to expand from the pyridinium aldoxime template to less space impacting nucleophiles.

A second consideration is based on the structural template of $\mathrm{AChE}$ in relation to the mechanisms of organophosphate reaction with the active centre of $\mathrm{AChE}$ and the subsequent reactivation reaction. The initial demonstration of a narrow and somewhat torturous gorge of some $18 \AA$ to $20 \AA$ in depth (8) poses a challenge particularly for the nucleophilic reactivation step forming active enzyme. Organophosphates, upon entering the gorge, orient their reactive groups such that the phosphoryl or phosphonyl oxygens associate with and become polarized by the oxyanion hole. This facilitates attack in a $\mathrm{SN}_{2}$-like mechanism by the active centre serine. By contrast, in the reactivation reaction, the narrow gorge is further impacted by
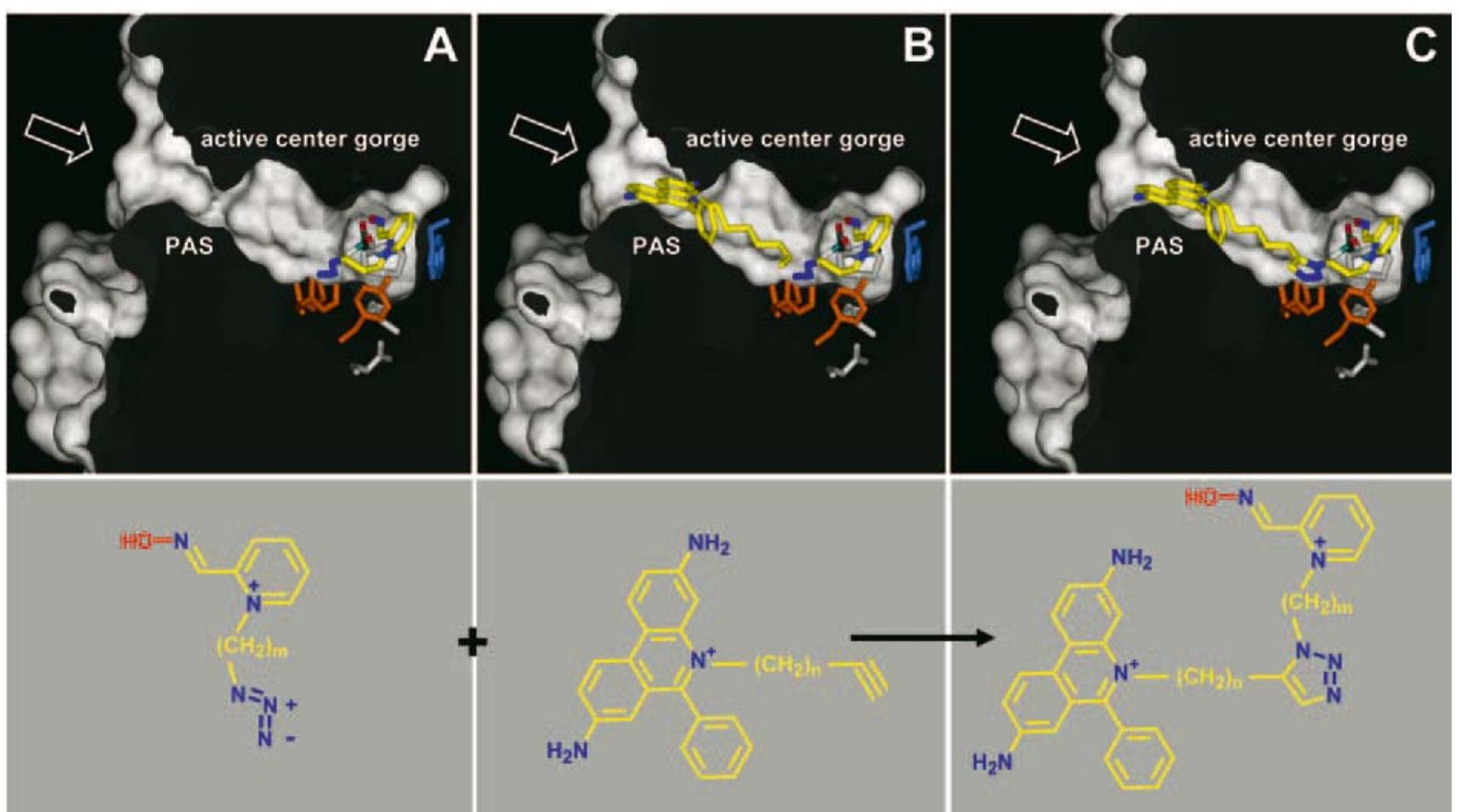

Figure 3 Proposed reaction between a peripheral site (PAS) extended acetylene (phenyl phenanthridinium linked to the acetylene through a methylene chain) and a 2-hydroxyiminomethyl-N-3-azidopropyl pyridinium. A mode of the positioning of these residues within the AChE active centre gorge is also depicted. The arrow indicates the entrance to the gorge. A) 2-hydroxyiminomethyl- $N$-3-azidopropyl pyridinium oxime ( $m=3$ in the formula below) bound at the base of the gorge. B) Ternary complex between the oxime and the PAS bound acetylene ( $n=5$ in the formula below) in the gorge. C) The hypothetical in situ acetylene + azide cycloaddition reaction product $(m=3, n=5)$ formed in the AChE active centre gorge. 
the conjugated organophosphate. Accordingly, the reactivation reaction cannot proceed by the hindside attack of the $\mathrm{SN}_{2}$ mechanism. This sub-optimal geometry likely accounts for the greatly diminished efficiency of the oxime reactivation reaction compared to inactivation, despite site directing the nucleophile to the active centre by virtue of the cationic charge and its spatial proximity to the active centre serine (4, $17,18)$. It is this consideration upon which "oximeassisted catalysis" of the offending organophosphate by a modified $\mathrm{AChE}$ is based.

\section{Oxime-assisted Catalysis}

To enhance the angle of access to the conjugated organophosphate, one might first turn to the acyl pocket region found in AChE to be lined with two phenylalanine side chains (Phe 295 and 297). In butyrylcholinsterase we find a leucine and isoleucine residues at those positions. The smaller and more flexible aliphatic side chains should provide greater space for the organophosphate as it does for acyl esters larger than propionylcholine. Similarly, one might expect diminished impaction with the entry of the oxime. However, the situation appears to be not that simple, for we find in many cases that oxime reactivation of organophosphates conjugated with $\mathrm{BChE}$ is slower than with AChE. Therefore, we began to dissect the residues contributing to the acyl pocket to ascertain whether we could enhance the reactivation reaction, thereby obtaining greater catalytic efficiency in cholinesterases hydrolyzing organophosphates.

Because of gorge impaction, the enhanced catalytic turnover of organophosphates can be expected to depend on three structural factors:

(i) the dimensions of the active centre of the enzyme and the gorge entry portal that will affect clearance of the entering oxime and the positioning of the conjugated organophosphate. From studies with $S_{\mathrm{p}}$ and $R_{\mathrm{p}}$ alkyl methylphosphonates conjugated to the active centre of $\mathrm{AChE}$, it is clear that occupation of the oxyanion hole, as in the case for inactivation, is essential for substantive reactivation efficiency (19-21). Therefore, upon nucleophilic attack, the conjugated organophosphate should be positioned so that the phosphonyl or phosphoryl bond can be polarized by the oxygen entry into the oxyanion hole. Gorge dimensions and positions of the critical residues can be, in part, modified through mutagenesis.

(ii) the structure of the organophosphate conjugate. The importance of this factor is evident from studies of the $R_{\mathrm{p}}$ and $S_{\mathrm{p}}$ methylphosphonate enantiomers (19-21), and from using various alkyl methylphosphonates and dialkyl phosphorates with alkyl groups of various sizes (22). For the organophosphates with larger alkyl groups, enlarging gorge dimensions through changing acyl pocket size influences reactivation of the more bulky organophosphates relative to the smaller one. This becomes evident from a comparison of reactivation of cycloheptyl and isopropyl methyl phosphonates.

(iii) the structure of the oxime or other candidate reactivating nucleophile. Here again, one can affect the attacking angle of the nucleophile by altering the distance between the nucleophile and the quaternary amine moiety. In other cases, one may wish to minimize the bulk in a 6-membered and incorporate 4- or 5-membered rings or to develop linear cationic nucleophiles. Passage across the blood-brain barrier might be achieved with bases of moderate $\mathrm{pK}_{\mathrm{a}}$ (8 to 9) and with ligands where the basic group is spread over resonance and conjugation such as the case of the amidines (23).

To demonstrate proof of principle, we have carried out mutations of several residues in the active centre of mouse and human $\mathrm{AChE}$, and examined the capacity for oximes to reactivate $\mathrm{AChE}$ conjugated by various $S_{\mathrm{p}}$ and $R_{\mathrm{p}}$ isopropyl, cycloheptyl and 3,3-dimethylbutyl methylphosphonates (Table 1). Enhancements of rates can be achieved by enlarging the acyl pocket through the substitution of aliphatic residues and enhancing clearance on the choline-occupying domain of the active centre, Tyr 337 (22). In fact, the combination of these mutations on the two sides of the gorge is the most successful (22), and $\sim 120$-fold increase in oxime-assisted catalytic turnover is achieved with $S_{p}$-cycloheptyl methylphosphonothiocholine. An analysis of the kinetics shows the rate-limiting step to be the oxime attack. Thus, our analysis can be independent of leaving group of the organophosphate used to form the conjugate. More detailed kinetic studies have been conducted to ascertain whether the mutations influence the affinity of the initial oxime complex, $K_{\mathrm{ox}}$, or the intrinsic rate of oxime attack, $k_{\text {cat' }}$, to break the phosphorus-oxygen bond.

It remains to be seen how far prospective mutagenesis will yield in enhanced rates for the various nerve agents that conjugate with the organophosphates, and a study varying the three parameters alluded to above is underway as a combined endeavour between groups in the United States, Croatia and Germany. Mutagenesis selection 
procedures involving somatic cell hypermutation provide an alternative approach of enhancing organophosphate catalysis (23).

\section{Acetylcholinesterase as a Detector of Organophosphate Exposure}

Recombinant DNA methods can also be used to modify AChE so that a chromophoric side chain is added to the enzyme at a position that changes conformation upon conjugation by an organophosphate or binding of a reversible inhibitor. Selection of the position for addition of the chromophoric side chain is critical, and this can be pursued by cysteine substitution mutagenesis through out the molecule. The omega loop, between residues 69 and 96 in mammalian cholinesterase is a good example, since this loop appears to cap the active centre gorge. Labelling residues distant from the site of binding results in a conformational change. For example, substitution of a cysteine at position 81 or 84 allows one to label the enzyme with a sulfhydryl modifying fluorophore such as acrylodan or a fluorescein derivative. Upon conjugation of the organophosphate characteristic changes in the fluorescence emission spectrum are evident. In some cases the spectral change is sensitive to the size and stereochemical characterisation of the organophosphate (24). This application is discussed in more depth in other reviews (2), and is applicable to measurements of decay of anisotropy to measure torsional, segmental and global motion in the macromolecule (25).

\section{REFERENCES}

1. Taylor P. Anticholinesterase Agents in Goodman and Gilman's Pharmacological Basis of Therapeutics. 10 ${ }^{\text {th }}$ ed. New York: McGraw-Hill; 2005.

2. Taylor P,KovarikZ, Reiner E, RadićZ. Acetylcholinesterase: Converting a vulnerable target to a template for antidotes and detection of inhibitor exposure. Toxicology 2007;233:70-8.

3. Giacobini E, editor. Cholinesterases and Cholinesterase Inhibitors. London: Martin Dunitz; 2000.

4. Wilson IB. Molecular complementarity and antidotes for organophosphate poisoning. Fed Proc 1959;18:7528.

5. Schumacher M, Camp S, Maulet Y, Newton M, Mac-Phee-Quigley K, Taylor S, Friedmann T, Taylor P. Primary structure of Torpedo californica acetylcholinesterase deduced from its cDNA sequence. Nature 1986;319:407-9.

Table 1 Second-order reactivation rate constants $(k)$ of recombinant DNA-derived mouse cholinesterases phosphonylated with chiral methyl phosphonyl thiocholines (MPTs). Modified from Kovarik et al. (21)

\begin{tabular}{|c|c|c|c|c|c|c|c|}
\hline \multirow{3}{*}{ Reactivator } & \multirow{3}{*}{ Enzyme } & \multicolumn{6}{|c|}{$k_{\mathrm{r}} / \mathrm{L} \mathrm{mol}^{-1} \mathrm{~min}^{-1}$} \\
\hline & & \multicolumn{2}{|c|}{ cycloheptyl MPT } & \multicolumn{2}{|c|}{ 3,3-dimethylbutyl MPT } & \multicolumn{2}{|c|}{ isopropyl MPT } \\
\hline & & $S_{p}$ & $R_{\mathrm{p}}$ & $S_{p}$ & $R_{\mathrm{p}}$ & $S_{p}$ & $R_{\mathrm{p}}$ \\
\hline \multirow{6}{*}{ HI-6 } & AChE w.t. & 112 & - & 102 & - & 1330 & 1.7 \\
\hline & Y337A & 2000 & 0.41 & 1200 & 0.74 & 240 & 7.3 \\
\hline & F295L/Y337A & 13180 & - & 1300 & - & 730 & 1.3 \\
\hline & F297I/Y337A & 2300 & - & 720 & - & 2330 & 0.13 \\
\hline & Y337A/F338A & 102 & - & 47 & 1.8 & 178 & - \\
\hline & BChE w.t. & - & - & 103 & - & 215 & 0.23 \\
\hline \multirow{6}{*}{ 2-PAM } & AChE w.t. & 0.66 & - & 0.18 & - & 1080 & 1.5 \\
\hline & Y337A & 4.1 & 1.3 & 0.041 & 1.8 & 82 & 4.3 \\
\hline & F295L/Y337A & 1.7 & - & 0.66 & - & 3.5 & 0.95 \\
\hline & F297I/Y337A & 6.9 & - & 0.27 & - & 534 & 0.041 \\
\hline & Y337A/F338A & 0.47 & 0.40 & 0.42 & - & 46 & - \\
\hline & BChE w.t. & - & 0.027 & 8.7 & 0.62 & 1250 & 0.88 \\
\hline
\end{tabular}

*Dash stands for insufficient reactivation level for kinetic analysis. 
6. Rachinsky T, Camp S, LiY, Ekstrom TJ, Newton M, Taylor P. Molecular cloning of mouse acetylcholinesterase: Tissue distribution of alternatively spliced mRNA species. Neuron 1990;5:317-27.

7. Lockridge O, Bartels CF, Vaughan TA, Wong CK, Norton SE, Johnson LL. Complete amino acid sequence of human serum cholinesterase. J Biol Chem 1987;262:549-57.

8. Sussman JL, Harel M, Frolow F, Oefner C, Goldman A, Toker L, Silman I. Atomic structure of acetylcholinesterase from Torpedo californica: a prototypic acetylcholine binding protein. Science 1991;253:872-9.

9. Bourne Y, Taylor P, Marchot P. Acetylcholinesterase inhibition by fasciculin: crystal structure of the complex. Cell 1995;83:493-506.

10. Radić Z. Pickering N, Vellom DC, Camp S, Taylor P. Three distinct domains in the cholinesterase molecule confer selectivity of acetyl- and butyrylcholinesterase inhibitors. Biochemistry 1993;32:12074-84.

11. Shafferman A, Ordentlich A, Barak D, Kronman C, Ber R, Bino T, Ariel N, Osman R, Velan B. Electrostatic attraction by surface charge does not contribute to the catalytic efficiency of acetylcholinesterase. EMBO J 1994;13:3448-55.

12. Radić Z, Kirchoff PD, Quinn DM, McCammon JM, Taylor P. Electrostatic influence on the kinetics of ligand binding to acetylcholinesterase. J Biol Chem 1997;272:23265-77.

13. Lewis WG, Green LG, Gynszpan F, Radić Z, Carlier PR, Taylor P, Finn MG, Sharpless KB. Click chemistry in situ: acetylcholinesterase as a reaction vessel for the selective assembly of femtomolar inhibitor from an array of building blocks. Angew Chem 2002;41:10537.

14. Manetsch R, Kransinski A, Radić Z, Raushel J, Taylor P, Sharpless KB, Kolb HC. In situ click chemistry: enzyme inhibitors made to their own specifications. J Am Chem Soc 2004;126:12809-18.

15. Bourne Y, Kolb HC, Radić Z, Sharpless KB Taylor P, Marchot P. Freeze-frame inhibitor captures acetylcholinesterase in a unique conformation. Proc Natl Acad Sci USA 2004;101:1449-54.
16. Radić Z, Manetsch R, Fournier D, Sharpless KB, Taylor P. Probing gorge dimensions of cholinesterases by freeze-frame click chemistry. In: The IX ${ }^{\text {th }}$ International Meeting on Cholinesterases; 6-10 May 2007; Suzhou, China. Program Book. p. 40. Abstract S-IV-2.

17. Wilson IB, Ginsburg S. A powerful reactivator of alkylphosphate-inhibited acetylcholinesterase. Biochim Biophys Acta 1955;18:168-70.

18. Ashani Y, Radić Z, Tsigelny I, Vellom DC, Pickering NA, Quinn DC, Doctor BP, Taylor P. Aminoacid residues controlling reactivation of organophosphonyl conjugates of acetylcholinesterase by mono-and bisquaternary oximes. J Biol Chem 1995;270:637080.

19. Hosea NA, Berman HA, Taylor P. Specificity and orientation of trigonal carboxyl esters and tetrahedral alkyl phosphonyl esters in cholinesterases. Biochemistry 1995;34:11528-36.

20. Wong L, Radić Z, Brüggeman RJM, Hosea N, Berman HA, Taylor P. Mechanism of oxime reactivation of acetylcholinesterase analyzed by chirality and mutagnesis. Biochemistry 2000;39:5750-7.

21. KovarikZ, Radić Z, Berman HA, Simeon-RudolfV, Reiner E, Taylor P. Mutant cholinesterases possessing enhanced capacity for reactivation of their phosphonylated conjugates. Biochemistry 2004;43:3222-9.

22. Kovarik Z, Radić Z, Berman HA, Simeon-Rudolf V, Reiner E, Taylor P. Acetylcholinestrerase active center and gorge conformations analysed by combinatorial mutations and enantiomeric phosphonates. Biochem J 2003;373:33-40.

23. Wang L, Jackson WC, Steinbach PA, Tsien RY. Evolution of new non-antibody proteins via iterative somatic hypermutation. Proc Natl Acad Sci USA 2004; 101:16745-9.

24. Shi J, Radić Z, Taylor P. Inhibitors of different structure induce distinguishing conformations in the omega loop, Cys ${ }^{69}$-Cys ${ }^{96}$, of mouse acetylcholinesterase. J Biol Chem 2002;277:43301-8.

25. Shi J, Tai K, McCammon JA, Taylor P, Johnson DA. Nanosecond dynamics of mouse acetylcholinesterase Cys $^{69}$-Cys ${ }^{96}$ omega loop. J Biol Chem 2003;278:3090511. 


\section{Sažetak}

\section{PRIMJENA TEHNOLOGIJE REKOMBINANTNE DNA ZA PRIPRAVKE KOLINESTERAZA KAO ANTIDOTA} I DETEKTORA ORGANOFOSFATA

Razvijajući novi pristup sintezi antidota pri otrovanju organofosfatima kao i njihovu detekciju, primijenili smo metode rekombinantne DNA za pripremu kolinesteraza s neuobičajenim svojstvima. Za antidotsku terapiju istražili smo mutacije prirodnih enzima miša i čovjeka koje povećavaju brzine reaktivacije oksimom. Takvi enzimi bi po unosu u cirkulaciju postali katalitički, a ne samo stehiometrijski odstranjivači organofosfata. Na taj način "oksimom potpomognuta kataliza" omogućava čišćenje organofosfata iz cirkulacije umanjujući prodiranje organofosfata u tkiva i njihovu toksičnost. Prema tome, oksim kao antidot ima dvojaku ulogu: u cirkulaciji i na razini tkiva. S druge strane, uporabom novog sintetskog pristupa u oblikovanju biološki aktivnih spojeva poznatog kao "klik kemija" diskretnih proteinskih konformacija, organofosforilirani konjugati acetilkolinesteraze služe kao kalup u sintezi novih nukleofilnih reaktivatora. Naposljetku, acetilkolinesteraza se može mutagenezom modificirati uvođenjem cisteina na koje se mogu vezati fluorofori. Fluorofori uvedeni na određena mjesta u molekuli acetilkolinesteraze mijenjaju svoja fluorescentna svojstva pri konjugaciji organofosfata s enzimom koji na taj način od objekta djelovanja insekticida i živčanih bojnih otrova postaje molekula za detekciju izloženosti organofosfatima.

KLJUČNE RIJEČl: acetilkolinesteraza, antidoti, detekcija, fluorescentna acetilkolinesteraza, in situ - klik kemija, kalup-dizajn lijekova, kataliza potpomognuta oksimom, kinetika reaktivacije, organofosfatni inhibitori

\section{CORRESPONDING AUTHOR:}

Palmer Taylor, Ph.D.

Department of Pharmacology

Skaggs School of Pharmacy \& Pharmaceutical Sciences

University of California, San Diego

La Jolla, CA 92093-0657, USA

E-mail:pwtaylor@ucsd.edu 